Check for updates

Cite this: RSC Adv., 2019, 9, 984

Received 3rd August 2018

Accepted 12th December 2018

DOI: $10.1039 / \mathrm{c} 8 \mathrm{ra06554c}$

rsc.li/rsc-advances

\section{Pilot-scale production of a highly thermostable $\alpha$-amylase enzyme from Thermotoga petrophila cloned into $E$. coli and its application as a desizer in textile industry}

\author{
Asma Zafar, ${ }^{* a}$ Muhammad Nauman Aftab, ${ }^{\text {tb }}$ Irfana lqbal, (D) ${ }^{c}$ Zia ud Din ${ }^{d}$ \\ and Mushtaq Ahmad Saleem ${ }^{a}$
}

In this study, the industrial applications of a highly thermostable $\alpha$-amylase as a desizer in the textile industry was evaluated. The cloned gene was expressed in different media (ZBM, LB, ZYBM9, and ZB) with IPTG (isopropyl $\beta$-D-1-thiogalactopyranoside) used as an inducer. Lactose was also used as an alternate inducer for the T7 promoter system in E. coli. For the large-scale production of the enzyme, different parameters were optimized. The maximum enzyme production was achieved when the volume of medium was $70 \%$ of the total volume of fermenter with a 2.0 vvm air supply and $20 \%$ dissolved oxygen at a $200 \mathrm{rpm}$ agitation rate. Under all the optimized conditions, the maximum enzyme production was $22.08 \mathrm{U} \mathrm{ml}^{-1} \mathrm{~min}^{-1}$ with lactose $(200 \mathrm{mM}$ ) as an inducer in ZBM medium. The desizing potential of the purified $\alpha$-amylase enzyme was calculated with different enzyme concentrations $\left(50-300 \cup \mathrm{ml}^{-1}\right)$ at different temperatures $\left(50-100^{\circ} \mathrm{C}\right)$, and $\mathrm{pHs}(4-9)$ with varying time intervals (30-120 min). The highest desizing activity was found when $150 \mathrm{U} \mathrm{ml}^{-1}$ enzyme units were utilized at $85^{\circ} \mathrm{C}$ and at $6.5 \mathrm{pH}$ for $1 \mathrm{~h}$.

\section{Introduction}

Amylases are starch-degrading enzymes that are capable of hydrolyzing the internal $\alpha-1-4$ glycosidic linkage in starch arranged in the form of polymers composed of glucose units. ${ }^{1}$ These enzymes are considered to be one of the most important industrial enzyme and make up about $25 \%$ of the world enzyme market and have proven significance for biotechnology. ${ }^{2,3}$ These enzymes are widely distributed throughout the biodiversity and can be obtained from various sources, such as animals, plants, and microorganisms; however, the microbial amylases are generally considered the most able to meet industrial requirements due to their stability and broad range of industrial applications. $^{4,5}$ Amylases are consequently used in many industrial applications, such as food, fermentation, textile desizing, paper, detergents, starch saccharification, and in the pharmaceutical industries. ${ }^{6,7}$

The thermostability of an enzyme is a desired characteristic for most industrial applications. As starch become soluble at $100{ }^{\circ} \mathrm{C}$ and above, most industrial applications of $\alpha$-amylases require their use at temperatures up to $110{ }^{\circ} \mathrm{C} .{ }^{8}$ To fulfil the

${ }^{a}$ Faculty of Life Sciences, University of Central Punjab, Lahore, Pakistan. E-mail: asma. zafar@ucp.edu.pk; Tel: +93006485797

${ }^{b}$ Institute of Industrial Biotechnology, Government College University, Lahore, Pakistan.E-mail:nauman535@yahoo.com

'Department of Zoology, Lahore College for Women University, Lahore, Pakistan

${ }^{d}$ University of Baluchistan, Quetta, Pakistan industrial demands for thermostable amylases with novel properties, the excursion must be constant., ${ }^{9,10}$ At an industrial scale, the growth of thermophilic organisms becomes difficult due to the rigorous growth requirements. ${ }^{11}$ This problem has been overcome in most cases by the application of recombinant DNA technology through gene cloning into the mesophilic host. $^{12}$

To obtain a high level of expression from the cloned genes there is a need to develop a novel process. ${ }^{13}$ A very efficient T7 expression system was developed into the E. coli strain BL21 for the heterologous expression of recombinant proteins. ${ }^{\mathbf{1 4}}$ T7 promoter-based pET vectors are the most commonly used vectors for the expression of recombinant proteins as first reported by Studier et al. ${ }^{15}$ IPTG is mostly used as an inducer to regulate the expression of recombinant genes under the influence of a promoter. However, there is a need for an alternative inducer as IPTG is very expensive and toxic to cells. ${ }^{16}$ As the natural inducer of lac operon, lactose is very cheap compared to IPTG and is harmless to the host cells, ${ }^{17}$ and is also used as a carbon source and energy source by cells. ${ }^{18}$

Optimization of the culture conditions and fermentation medium to reduce the costs and to achieve maximum enzyme production was the key aim of the present research. Different fermentation techniques, including submerged fermentation and solid-state fermentation techniques, have been applied in practice. Submerged fermentation is a process of choice for many industrial applications due to various reasons, including 
good process control, effective bioreactor design, and it allows fermentation modeling. ${ }^{19}$ With respect to downstream processing, submerged fermentation has clear advantages in terms of the costs related to components involved in the medium. ${ }^{20}$

The large-scale production of $\alpha$-amylase is attracting much research attention due to the effective development in fermentation techniques. ${ }^{21}$ In biotechnological processes, maximizing enzyme production is becoming one of the most important goals. $^{22}$ The production of enzymes can be boosted by optimizing the culture conditions, like the inoculum size, dissolved oxygen level, rate of agitation, and agitation itself. ${ }^{23}$

In the textile industry, amylases are used in the desizing of cotton cloth. Starch is a sizing agent that is commonly used in the manufacturing process of cloth to strengthen the thread before fabric production by forming a layer on it. This layer is later removed from the woven cloth in the textile finishing industry by the application of amylase, which effectively removes the starch without damaging the fibers. ${ }^{7,24}$ With the introduction of mesophilic, thermostable, and alkaliphile amylases from bacterial sources enzymatic desizing is preferred due to their stability against the chemicals in the desizing liquor. ${ }^{25}$ Depending upon the enzyme reaction type, the temperature conditions and the mass transfer actions in the process, the degradation of starch takes the longest time among the various steps involved in desizing. Due to this reason, thermostable amylases are attracting more interest because their use can shorten the process duration to allow a similar efficiency as that of mesophilic amylases and conventional processes. $^{26}$

This study aimed to optimize all the essential parameters in order to develop a fermentative strategy for the large-scale production of cloned $\alpha$-amylase from Thermotoga petrophila into $E$. coli and to evaluate the desizing potential of the $\alpha$ amylase.

\section{Methodology}

\section{Selection of bacterial strains and plasmids}

Thermotoga petrophila genomic DNA was purchased from DSMZ's German collection of cell cultures and microorganisms, Germany, and was used for amplification of the amylase gene. The pET 21a (+) vector was used to express the amylase gene in E. coli BL21.

\section{Cloning of the $\alpha$-amylase gene from Thermotoga petrophila in pET-21a (+)}

Amplification of the amylase gene of Thermotoga petrophila was carried out using genomic DNA as a template. Primers were designed from a DNA sequence retrieved from the NCBI database (GenBank accession number NC_009486.1). DNASTAR software was used for designing the primer. An NdeI restriction site was introduced on the $5^{\prime}$ end of the forward primer and a HindIII restriction site was introduced on the $5^{\prime}$ end of the reverse primer. The nucleotide sequences of the pair of primers were as follows:

Forward 5'-CATATGCTTTTGAGAGAGATAAACCGATACTGC-3'
Reverse 5 -TCACTCCTGTACAACAAGAACAAAATCAAGGGGT-3 ${ }^{\prime}$

The PCR product obtained was analyzed on $1 \%$ agarose gel and purified using a DNA purification kit from Qiagen. The purified amplified Thermotoga petrophila $\alpha$-amylase gene (1914 bp) was double digested with the restriction enzymes NdeI and HindIII. The digested gene was purified and ligated with doubledigested pET-21a (+). Freshly prepared competent cells of E. coli BL21 (DE3) ${ }^{27}$ were used as the host organism for transformation of the recombinant vector pET 21a $(+)$ containing the $\alpha$-amylase gene. Positive clones were screened by restriction analysis of the pET 21a $(+)$ plasmid containing the $\alpha$-amylase gene with HindIII and NdeI.

\section{Expression of the recombinant $\alpha$-amylase gene in $E$. coli BL21}

For expression of the recombinant enzyme, transformed E. coli BL21 cells were grown in Luria-Bertani medium ( 0.1 liter) containing $100 \mu \mathrm{g} \mathrm{ml}^{-1}$ ampicillin at $37^{\circ} \mathrm{C}$, to an optical density of $0.5-0.7$ at $600 \mathrm{~nm}$. Then, $0.5 \mathrm{mM}$ isopropyl-D-thiogalactopyranoside (IPTG) was used as an inducer and the cells were incubated at $37{ }^{\circ} \mathrm{C}$ for an additional $4 \mathrm{~h}$. After $4 \mathrm{~h}$ incubation, the cells were harvested by centrifugation $(6000 \mathrm{rpm}$, $10 \mathrm{~min}, 4^{\circ} \mathrm{C}$ ). The cell were lysed by sonication for $10 \mathrm{~min}$ after resuspension in $5 \mathrm{ml}$ of $50 \mathrm{mM}$ Tris- $\mathrm{HCl}$ (pH 7.5 to 8) and then centrifuged at $12000 \mathrm{rpm}$ for $10 \mathrm{~min}$. Total protein concentration was determined using the method given by Bradford. ${ }^{28}$ Then, $\alpha$-amylase expression was determined in the extracellular as well as in intracellular fractions by running 12\% SDS-PAGE, visualized with Coomassie blue. ${ }^{29}$

\section{Fermentation techniques}

Stirring fermenter. Fermentation was performed at $37^{\circ} \mathrm{C}$ for $4 \mathrm{~h}$ in a glass fermenter of 7.5 L (Bioflo 110, Brunswick Scientific, USA). LB medium was autoclaved at $121{ }^{\circ} \mathrm{C}$ and $15 \mathrm{lb}$ per $\mathrm{in}^{2}$ pressure for $30 \mathrm{~min}$. Aseptic conditions were used to transfer the inoculum, which was incubated at $22{ }^{\circ} \mathrm{C}$. The agitation and aeration rates were maintained at $200 \mathrm{rpm}$ and $2.0 \mathrm{vvm}$, until the optical density reached up to 0.6. Air was sterilized using a membrane filter of $0.4 \mu \mathrm{m}$. For the control, frothing sterilized silicone oil (10\%) was used. When the optical density reached 0.6 , the cells were induced by $0.5 \mathrm{mM}$ IPTG and incubated at $22{ }^{\circ} \mathrm{C}$ for $4 \mathrm{~h}$. Fermented broth was centrifuged for $20 \mathrm{~min}$ at $6000 \mathrm{~g}$ and $4{ }^{\circ} \mathrm{C}$. The supernatant was stored at $4{ }^{\circ} \mathrm{C}$ and the $E$. coli cells were sonicated. The clear cell lysate and supernatant were used for intracellular and extracellular enzyme estimation, respectively. The effects of various parameters utilized in the stirred fermenter are mentioned below:

1. Effect of agitation. To determine the effect of agitation on $\alpha$-amylase production in the stirred fermenter, $100-300 \mathrm{rpm}$ agitation speed was utilized with a $3 \%$ inoculum size and $20 \%$ dissolved oxygen level, $60 \%$ volume of fermentation medium, and $3 \mathrm{vvm}$ aeration rate.

2. Effect of the inoculum. To determine the effect of the inoculum, the fermentation medium was inoculated with varying percentages (1-6\%) of inoculums, with the other conditions being $200 \mathrm{rpm}$ agitation rate, $20 \%$ dissolved oxygen 
level, $60 \%$ volume of fermentation medium, and $3 \mathrm{vvm}$ aeration rate.

3. Effect of dissolved oxygen. Various dissolved oxygen levels, ranging from $10-30 \%$, were analyzed by providing $3 \%$ inoculum at $200 \mathrm{rpm}$ agitation speed and $3 \mathrm{vvm}$ aeration rate using $60 \%$ volume of fermentation medium in order to obtain the maximum enzyme production.

4. Effect of the volume of the fermentation medium. To determine the effect of the volume of the fermentation medium for achieving the maximum enzyme production, different volumes from $40-90 \%$ of the fermentation medium were used in a stirred fermenter, with the other conditions being $3 \%$ inoculum size, $200 \mathrm{rpm}$ agitation speed, $20 \%$ dissolved oxygen level, and $3 \mathrm{vvm}$ aeration rate.

5. Effect of the aeration rate. The effect of varying the rate of aeration on the production of recombinant $\alpha$-amylase was studied at different aeration levels (0.5-3.0 vvm), with the other conditions being $3 \%$ inoculum size, $200 \mathrm{rpm}$ agitation rate, $20 \%$ dissolved oxygen level, and $70 \%$ volume of the medium.

Enzyme assay. Enzyme activity was analyzed using the DNS (dinitrosalicylic acid) method $^{30}$ by determination of the reducing sugars. Maltose was used as a standard to measure the liberated reducing sugars in a spectrophotometer at $550 \mathrm{~nm}$. Enzyme activity was defined as "the quantity of enzyme that was used to release reducing sugar (one $\mu$ mole) from a substrate under specific conditions".

Protein assay. The Bradford method ${ }^{28}$ was used for estimation of the total proteins using bovine serum albumin as standard. Here, $0.2 \mathrm{ml}$ of enzyme and $5.0 \mathrm{ml}$ of Bradford reagent were mixed at room temperature and the absorbance was measured after $5 \mathrm{~min}$ at $595 \mathrm{~nm}$ in a spectrophotometer. A blank (without enzyme) was run in parallel containing distilled water instead of the enzyme.

\section{Media optimization with lactose and IPTG as the inducer}

Different media (M9, LB, ZB, ZBM, and ZYBM9) were optimized to get the maximum production of recombinant $\alpha$-amylase by utilizing lactose and the IPTG alternate inducer for the T7 expression system.

\section{Industrial applications of the recombinant $\alpha$-amylase}

Desizing with alpha amylase. To check the desizing activity of the recombinant enzyme, a piece of grey fabric was used having maximum starch on it. A plain weaved, 100\% cotton grey fabric was used in this experiment. The sized fabric was dipped in boiling water $\left(100{ }^{\circ} \mathrm{C}\right)$ for almost $2 \mathrm{~min}$ to facilitate the swelling of the starch layer. A fabric piece $(5 \times 5$ inches $)$ was preweighed and used for further analysis. The alignment of the warps and wefts in the plain weaved fabric was done a simple crisscross pattern ${ }^{31}$ that is used more than any other weave. Plain weaved fabric is stronger than any other weave type due to the presence of a greater number of intersections per unit space, all other factors being equal. ${ }^{32}$ The pre-weight of the cloth having starch on it was calculated to be $13.78 \mathrm{~g}$. Total fiber count was 120 epi in the grey fabric used in this study. The fabric was dipped in $\alpha$-amylase solution (pH 7.0, $100 \mathrm{ml}$ ) and then incubated at $80{ }^{\circ} \mathrm{C}$ for $1.0 \mathrm{~h}$. After $1 \mathrm{~h}$ incubation, washing was carried out with distilled water and the fabric strip was then dried in an oven. After complete drying, the strip was weighed again.

$$
\text { Weight of starch removed }=\text { initial weight }- \text { final weight. }
$$

The \% removal of starch was calculated by applying the following formula:

$$
\text { Desizing }(\%)=\frac{\text { Wt. of starch removed by enzyme }}{\text { Total starch present on the fabric strip }}
$$

The total starch present in the grey fabric was calculated by hydrolyzing the starch with $\mathrm{H}_{2} \mathrm{SO}_{4}(0.1 \mathrm{~N}) .^{33-38}$

Optimization of the cotton cloth desizing. The effect of different parameters, such as $\mathrm{pH}$ (4-9), temperature of incubation (50-100 $\left.{ }^{\circ} \mathrm{C}\right)$, enzyme concentration $(50-300 \mathrm{U}$ $\mathrm{ml}^{-1} \mathrm{~min}^{-1}$ ), time of incubation (30-120 $\mathrm{min}$ ), effect of agitation rate $(50-250 \mathrm{rpm})$, effect of various metal ions $(10 \mathrm{mM})$ $\left(\mathrm{Mg}^{2+}, \mathrm{Cu}^{2+}, \mathrm{Ca}^{2+}, \mathrm{Co}^{2+}, \mathrm{Na}^{1+}, \mathrm{K}^{1+}, \mathrm{NH}_{4}{ }^{1+}\right.$, and $\left.\mathrm{Ni}^{2+}\right)$ at a concentration of $10 \mathrm{mM}$, and effect of different wetting agents (SDS, Tween 20, Tween 80, Triton X-100, CTAB, CABP) at a concentration of $10 \mathrm{mM}$ were studied to investigate the maximum desizing potential of the recombinant $\alpha$-amylase for use in the textile industry. The desizing efficiency of the recombinant $\alpha$-amylase enzyme was determined by iodine solution test.

\section{Results and discussion}

Thermostable enzymes are required for all industrial processes that are usually carried out at very high temperature. ${ }^{39}$ The textile industry uses crude amylase for the desizing of grey fabric as a very auspicious process in cloth processing: ${ }^{35}$

\section{Cloning of amylase gene in the expression vector pET-21a (+)}

Amplification of an amylase gene from $T$. petrophila was carried out using a specific pair of primers. A specific amplified band (1920 bp) (Fig. 1) was purified and double digested using the restriction enzymes NdeI and HindIII. The purified doubledigested and amplified amylase gene was ligated into the pET21a (+) vector with the help of T4 DNA ligase. The recombinant vector pET21a (+)/amylase, was introduced into the freshly prepared competent cells of E. coli BL21 (DE3). Cloning of the amylase gene was confirmed by double digesting it with HindIII and NdeI and by sequencing the clone gene. After a single digestion of recombinant plasmid with HindIII, a band of 7320 bp was observed (Fig. 1) confirming the cloning of amylase gene in the pET21a $(+)$ vector.

\section{Expression of the cloned amylase gene}

Both intracellular as well as extracellular enzyme samples were analyzed for amylase activity. To obtain the intracellular enzyme fraction, the cultivated bacterial cells were subjected to 


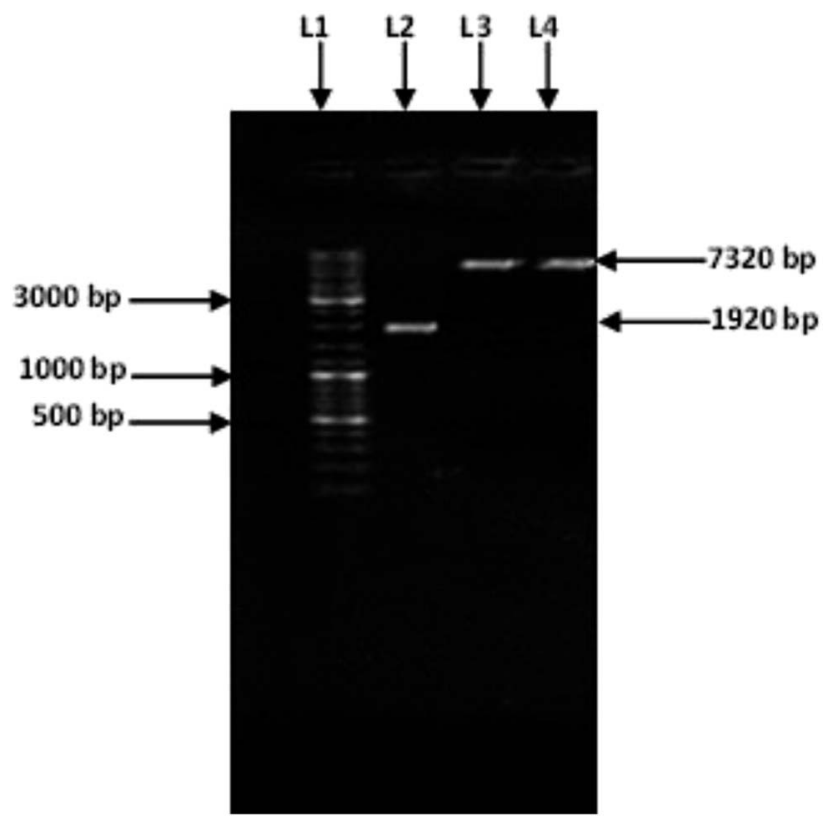

Fig. 1 Amplified amylase gene: the GeneRulerTM DNA ladder (Lane 1), PCR product of the amylase gene 1920 bp (Lane 2), single digested recombinant pET 21a (+) containing the amylase gene (Lanes 3 and 4).

sonication for lyses in a heat sonicator system. In the intracellular fraction, $2.5 \mathrm{U} \mathrm{ml}^{-1} \mathrm{~min}^{-1}$ of amylase activity was found. However, minute activity of the amylase enzyme was observed in the extracellular samples. SDS-PAGE analysis was also done for both (extracellular and intracellular fractions) samples to ensure the successful expression of the amylase gene of $T$. petrophila into E. coli BL21 (DE3). A protein marker, positive (BL21 containing pET 21a $(+)$ without the gene) and negative controls (wild BL21 DE3) were also run in parallel. A band of almost 70 $\mathrm{kDa}$ was found in the intracellular enzyme fraction, as shown in Fig. 2, while no such band was observed in the positive and negative controls at the same position. However, a very light protein band was seen at the same position in the extracellular enzyme fraction (Fig. 2).

\section{Optimization of the parameters for $\alpha$-amylase production}

This study was concerned with the scale-up studies of cloned $\alpha$ amylase from Thermotoga petrophila for high production by optimization of different parameters and evaluation of the recombinant amylase for its desizing potential. These studies were carried out in a $7.5 \mathrm{~L}$ glass fermenter fitted with a $5 \mathrm{~L}$ round-bottom flask. For high recombinant $\alpha$-amylase production, the following parameters were optimized during the fermenter studies.

\section{Influence of the agitation rate}

A continuous supply of oxygen to the microorganism in the fermentation medium depends on the agitation intensity. To determine the effect of agitation on $\alpha$-amylase production in the stirred fermenter, a 100-300 rpm agitation speed was utilized together with a $3 \%$ inoculum size with $20 \%$ dissolved oxygen

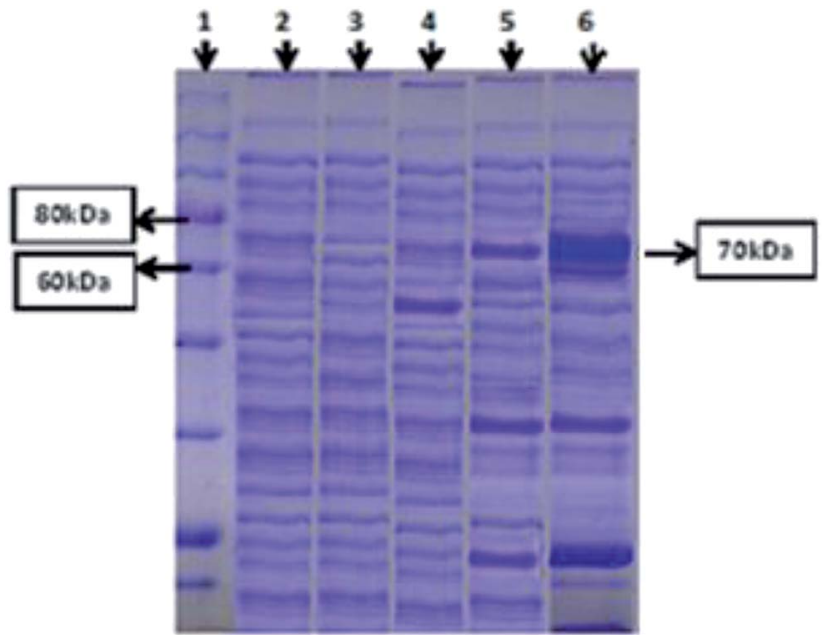

Fig. 2 SDS-PAGE study of recombinant amylase gene expression. Protein marker (Lane 1), extract of wild E. coli (Lane 2), vector only without insert (Lane 3), vector plus amylase gene, non-induced (Lane 4), vector plus amylase gene, induced, extracellular fraction (Lane 5), vector plus amylase gene, induced, intracellular fraction (Lane 6). The results are for $70 \mathrm{kDa} \alpha$-amylase in the intracellular fraction.

level, $60 \%$ volume of medium, and $3 \mathrm{vvm}$ aeration rate. The highest enzyme activity $\left(5.43 \pm 0.08 \mathrm{U} \mathrm{ml}^{-1} \mathrm{~min}^{-1}\right)$ was obtained at $200 \mathrm{rpm}$ with $4.69 \pm 0.14 \mathrm{mg} \mathrm{ml} \mathrm{m}^{-1}$ total protein (Fig. 3). A further increase in the agitation intensity resulted in decreased enzyme production, mainly due to the oxidative stress and disproportionate foaming to the organism. A low agitation intensity also had a marked impact on enzyme production due to the limited oxygen supply to the bacterial cells and poor mixing of the medium for fermentation. At 100 and $150 \mathrm{rpm}$, the enzyme activity was calculated to be $2.2 \pm 0.14$ $\mathrm{U} \mathrm{ml}^{-1} \min ^{-1}$ and $4.114 \pm 0.08 \mathrm{U} \mathrm{ml}^{-1} \mathrm{~min}^{-1}$ and the total protein was $1.916 \pm 0.05 \mathrm{mg} \mathrm{ml}^{-1}$ and $2.958 \pm 0.07 \mathrm{mg} \mathrm{ml}^{-1}$ (Fig. 3). At other agitation rates of 100, 150, 250, and $300 \mathrm{rpm}$, enzyme expression was calculated as $4.114 \pm 0.08 \mathrm{U}$ $\mathrm{ml}^{-1} \min ^{-1}, 2.2 \pm 0.14 \mathrm{U} \mathrm{ml}^{-1} \min ^{-1}, 1.180 \pm 0.12 \mathrm{U}$ $\mathrm{ml}^{-1} \mathrm{~min}^{-1}$, and $4.243 \pm 0.08 \mathrm{U} \mathrm{ml}^{-1} \mathrm{~min}^{-1}$, while the total protein contents were $1.1198 \pm 0.07 \mathrm{mg} \mathrm{ml}^{-1}, 1.916 \pm 0.05 \mathrm{mg}$ $\mathrm{ml}^{-1}, 3.12 \pm 0.07 \mathrm{mg} \mathrm{ml} \mathrm{m}^{-1}$, and $2.958 \pm 0.07 \mathrm{mg} \mathrm{ml} \mathrm{m}^{-1}$,

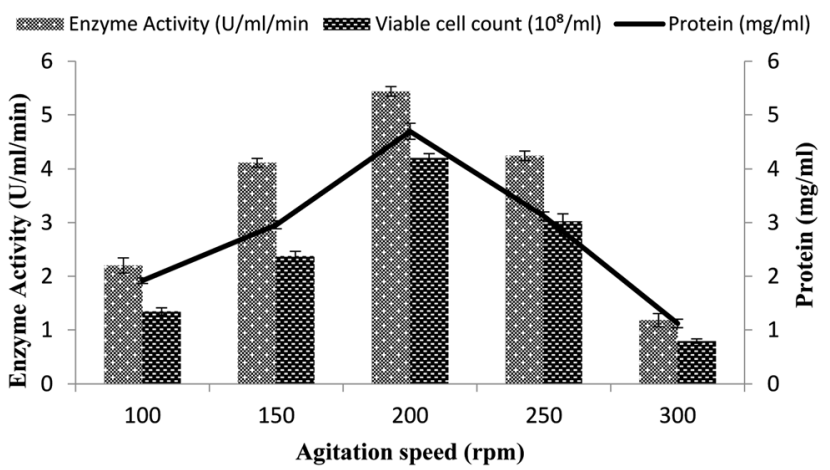

Fig. 3 Effect of the rate of agitation on amylase activity in the stirred fermenter at an initial temperature of $22{ }^{\circ} \mathrm{C}$ and $\mathrm{pH}$ of 7.0. 
respectively. The total viable cell counts were $1.34 \times 10^{8} / \mathrm{ml}$, $2.37 \times 10^{8} / \mathrm{ml}, 4.2 \times 10^{8} / \mathrm{ml}, 3.0 \times 10^{8} / \mathrm{ml}$, and $0.79 \times 10^{8} / \mathrm{ml}$ at 100, 150, 200, 250, and $300 \mathrm{rpm}$, respectively (Fig. 3). However, Haq et $a .^{35}$ in their fermenter studies reported the maximum amylase production from Bacillus amyloliquefaciens at $400 \mathrm{rpm}$.

\section{Effect of the inoculum size}

The size of the inoculums is also an important factor in the fermentation reactions. ${ }^{40}$ A range of inoculum sizes (1-6\%) that yielded viable cells $\left(2.2 \times 10^{8}\right.$ to $\left.3.45 \times 10^{8} \mathrm{ml}^{-1}\right)$ were utilized for the optimization process in the stirred fermenter. The fermenter medium was inoculated with varying percentages (1$6 \%$ ) of inoculums, with setting the conditions as a $200 \mathrm{rpm}$ agitation rate, $20 \%$ dissolved oxygen level, $60 \%$, volume of the medium, and $3 \mathrm{vvm}$ aeration rate. The maximal enzyme activity obtained was $5.50 \pm 0.13 \mathrm{U} \mathrm{ml}^{-1} \mathrm{~min}^{-1}$ with $3 \%$ inoculum having $4.61 \pm 0.18 \mathrm{mg} \mathrm{ml}^{-1}$ total protein content and $4.74 \times$ $10^{8} / \mathrm{ml}$ total viable cell count as shown in Fig. 4 . A decline in enzyme activity was observed when a higher \% age of inoculum was used. Similarly, $\alpha$-amylase production was reduced when less than $3 \%$ inoculum was added. The $\alpha$-amylase activity was found to be $2.24 \pm 0.09 \mathrm{U} \mathrm{ml}^{-1} \mathrm{~min}^{-1}$ and $3.35 \pm 0.08 \mathrm{U}$ $\mathrm{ml}^{-1} \mathrm{~min}^{-1}$ with a total protein content of $2.0 \pm 0.08 \mathrm{mg} \mathrm{ml}^{-1}$ and $3.12 \pm 0.10 \mathrm{mg} \mathrm{ml}^{-1}$ and viable cell count of $1.32 \times 10^{8} / \mathrm{ml}$ and $2.15 \times 10^{8} / \mathrm{ml}$ when $1 \%$ and $2 \%$ inoculum was added, respectively (Fig. 4). This result revealed that a lower inoculum size yielded an inadequate microorganism growth, which resulted in competitive inhibition, ${ }^{\mathbf{4 1}}$ whereas more than $3 \%$ inoculum resulted in increased microorganism growth, which resulted in depletion of the nutrients and in turn reduction of the metabolic activity ${ }^{\mathbf{4 2}}$ and the accretion of other byproducts in the medium. ${ }^{35}$

\section{Effect of dissolved oxygen}

A continuous supply of oxygen is necessary for aerobic fermentation by the organism present in the dissolved form in the medium. Various dissolved oxygen levels ranging from 10$30 \%$ were analyzed by providing $3 \%$ inoculum at $200 \mathrm{rpm}$ agitation speed and $3 \mathrm{vvm}$ aeration rate and by setting the volume of the medium as $60 \%$ in order to achieve the maximum

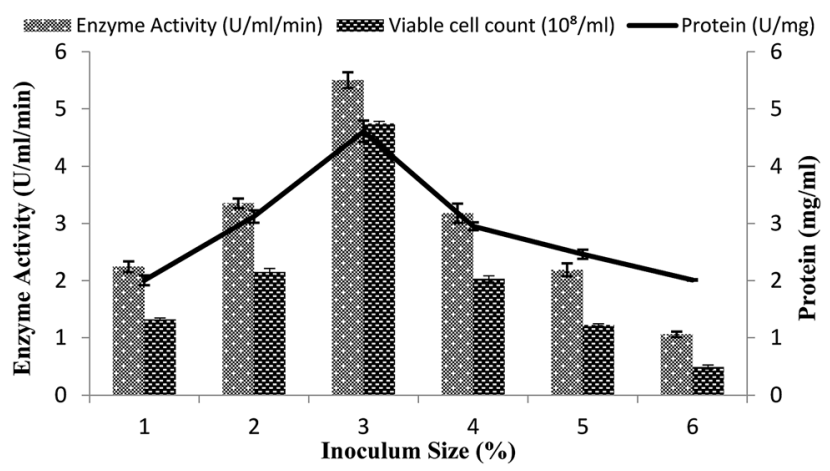

Fig. 4 Effect of the inoculum size on amylase activity in the stirred fermenter at an initial $\mathrm{pH}$ of 7.0 and temperature of $22{ }^{\circ} \mathrm{C}$. enzyme production. In the present study, the maximum amylase production (5.68 $\mathrm{U} \mathrm{ml}^{-1} \mathrm{~min}^{-1}$ ) was obtained when $20 \%$ dissolved oxygen was present in the medium, as shown in Fig. 5. Low and high concentrations of oxygen levels might have a detrimental effect on the microorganisms and may retard their growth. ${ }^{43}$ At high concentration, oxygen may cross the saturation level, leading to the formation of many toxic compounds, like superoxide and hydrogen peroxide, in the fermentation media. ${ }^{\mathbf{4}-46}$ At the other $10 \%, 15 \%, 25 \%$, and $30 \%$ levels of dissolved oxygen, low enzyme activity was obtained $\left(2.11 \pm 0.08 \mathrm{U} \mathrm{ml}^{-1} \mathrm{~min}^{-1}, 3.77 \pm 0.06 \mathrm{U} \mathrm{ml}^{-1} \mathrm{~min}^{-1}, 4.15 \pm\right.$ $0.04 \mathrm{U} \mathrm{ml}^{-1} \mathrm{~min}^{-1}$, and $\left.2.0 \pm 0.08 \mathrm{U} \mathrm{ml}^{-1} \mathrm{~min}^{-1}\right)$ and less total protein content was obtained $\left(4.11 \pm 0.08 \mathrm{mg} \mathrm{ml}^{-1}, 3.09 \pm\right.$ $0.11 \mathrm{mg} \mathrm{ml}^{-1}, 4.96 \pm 0.13 \mathrm{mg} \mathrm{ml}^{-1}$, and $3.99 \pm 0.1 \mathrm{mg} \mathrm{ml}^{-1}$ ) and viable cell count $\left(2.53 \times 10^{8} / \mathrm{ml}, 1.17 \times 10^{8} / \mathrm{ml}, 1.39 \times 10^{8} /\right.$ $\mathrm{ml}$, and $3.51 \times 10^{8} / \mathrm{ml}$ ) were achieved (Fig. 5). Abdullah et al. ${ }^{22}$ claimed increased amylase production from Aspergillus oryzae in a stirred fermenter with $15 \%$ dissolved oxygen.

\section{Effect of fermentation medium volume}

The volume of the fermentation medium exhibited an important role during the production of enzymes as in the case for Bacillus sp. using submerged fermentation. ${ }^{47}$ Aeration and agitation affected the enzyme production and also affected the growth of the organisms. To determine the effect of the volume of fermentation medium for maximum enzyme production, different volumes $40-90 \%$ of the fermentation medium were used in a stirred fermenter, while setting the other condition as $3 \%$ inoculum size, $200 \mathrm{rpm}$ agitation speed, $20 \%$ dissolved oxygen level, and $3 \mathrm{vvm}$ aeration rate. The maximum enzyme production (6.07 $\mathrm{U} \mathrm{ml}^{-1} \mathrm{~min}^{-1}$ ) with $70 \%$ volume of medium suggested that, at increased levels of medium volume, the growth of microorganisms was restricted as the supply of oxygen decreased and also as the availability of nutrients decreased due to the inadequate agitation. ${ }^{48}$ Total calculated protein content was $5.15 \pm 0.13 \mathrm{mg} \mathrm{ml}^{-1}$ and viable cell count was $5.5 \times 10^{8} / \mathrm{ml}$ when utilizing a working volume of $70 \%$, as shown in Fig. 6. A reasonable amount of enzyme activity $(5.49 \pm$ $0.08 \mathrm{U} \mathrm{ml}^{-1} \mathrm{~min}^{-1}$ ) with a total protein content of $4.31 \pm$ $0.18 \mathrm{mg} \mathrm{ml}^{-1}$ and viable cell count of $4.35 \times 10^{8} / \mathrm{ml}$ was also

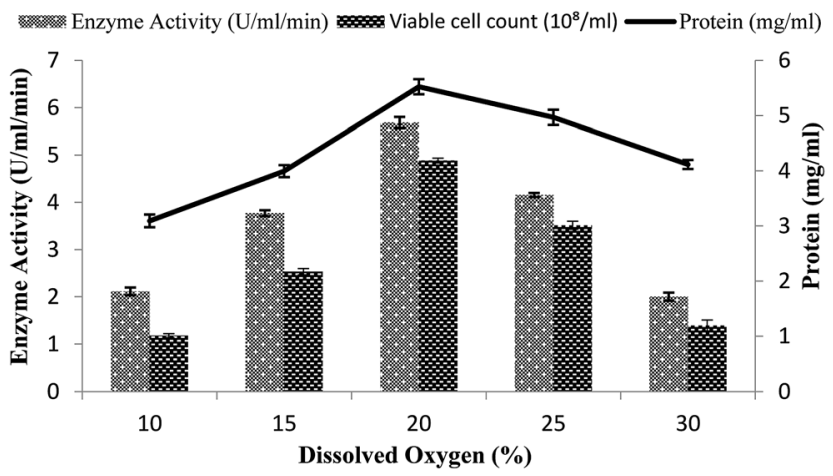

Fig. 5 Effect of dissolved oxygen on the amylase activity in the stirred fermenter at an initial $\mathrm{pH}$ of 7.0 and temperature of $22{ }^{\circ} \mathrm{C}$. 


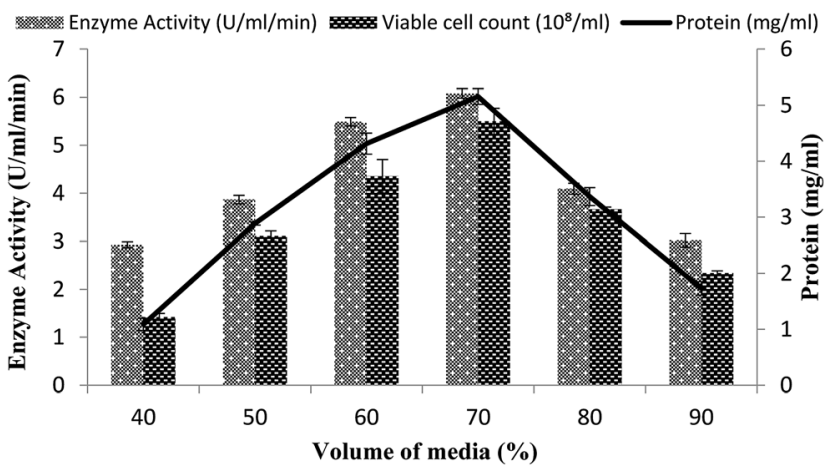

Fig. 6 Effect of the medium volume on the activity of amylase in a stirred fermenter at an initial $\mathrm{pH} 7.0$ and temperature of $22{ }^{\circ} \mathrm{C}$.

obtained when a $60 \%$ working volume was used (Fig. 6). Very less enzyme activity, i.e., $2.92 \pm 0.06 \mathrm{U} \mathrm{ml}^{-1} \mathrm{~min}^{-1}$ and $3.01 \pm$ $0.13 \mathrm{U} \mathrm{ml}^{-1} \mathrm{~min}^{-1}$ with a total protein content of $1.08 \pm 0.1 \mathrm{mg}$ $\mathrm{ml}^{-1}$ and $1.73 \pm 0.12 \mathrm{mg} \mathrm{ml}^{-1}$, was observed when $40 \%$ and $90 \%$ working volumes were utilized while the viable cell counts were $1.42 \times 10^{8} / \mathrm{ml}$ and $2.34 \times 10^{8} / \mathrm{ml}$, respectively.

\section{Effect of rate of aeration}

The effect of the rate of aeration on the production of recombinant $\alpha$-amylase was studied by different aeration levels $(0.5-3.0 \mathrm{vvm})$, with setting the other conditions as $3 \%$ inoculum size, $200 \mathrm{rpm}$ agitation rate, $20 \%$ dissolved oxygen level, and $70 \%$ volume of the medium. The maximum enzyme activity $\left(6.17 \pm 0.03 \mathrm{U} \mathrm{ml}^{-1} \mathrm{~min}^{-1}\right)$ was observed at an aeration level of $2.0 \mathrm{vvm}$ with $5.59 \pm 0.04 \mathrm{mg} \mathrm{ml}^{-1}$ total protein content and a viable cell count of $5.82 \times 10^{8} / \mathrm{ml}$ (Fig. 7). At aeration rates of $0.5,1.0,1.5,2.5$, and $3.0 \mathrm{vvm}$, the enzyme activity was $3.16 \pm$ $0.06 \mathrm{U} \mathrm{ml}^{-1} \mathrm{~min}^{-1}, 2.10 \pm 0.02 \mathrm{U} \mathrm{ml}^{-1} \min ^{-1}, 1.27 \pm 0.06 \mathrm{U}$ $\mathrm{ml}^{-1} \min ^{-1}, 4.55 \pm 0.08 \mathrm{U} \mathrm{ml}^{-1} \mathrm{~min}^{-1}$, and $5.37 \pm 0.06 \mathrm{U}$ $\mathrm{ml}^{-1} \mathrm{~min}^{-1}$, with total protein content of $4.2008 \pm 0.0103 \mathrm{mg}$ $\mathrm{ml}^{-1}, 2.904 \pm 0.0354 \mathrm{mg} \mathrm{ml}^{-1}, 4.169 \pm 0.063 \mathrm{mg} \mathrm{ml}^{-1}, 1.794 \pm$ $0.04 \mathrm{mg} \mathrm{ml}^{-1}, 5.001 \pm 0.0151 \mathrm{mg} \mathrm{ml}^{-1}$, and viable cell count of $1.51 \times 10^{8} / \mathrm{ml}, 2.45 \times 10^{8} / \mathrm{ml}, 4.46 \times 10^{8} / \mathrm{ml}, 4.28 \times 10^{8} / \mathrm{ml}$, and $0.86 \times 10^{8} / \mathrm{ml}$, respectively (Fig. 7). It has been reported that higher aeration rates have an adverse effect on the enzyme

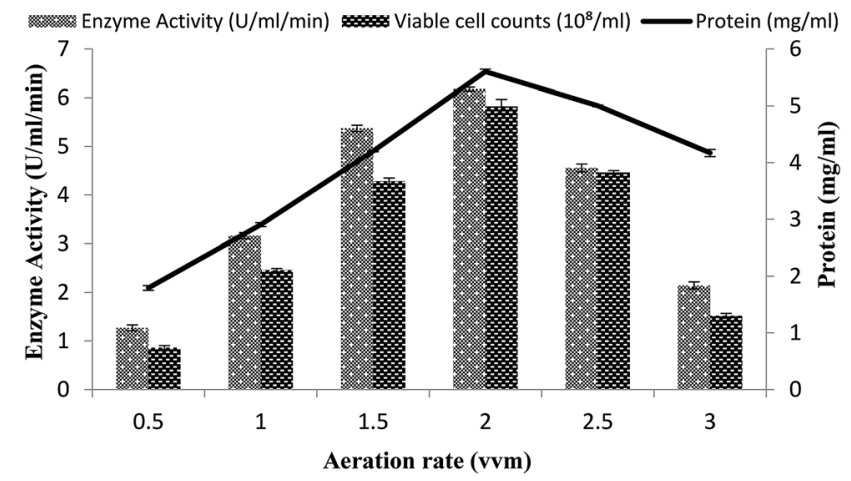

Fig. 7 Effect of the rate of aeration on amylase activity in the stirred fermenter at an initial temperature of $22^{\circ} \mathrm{C}$ and $\mathrm{pH}$ 7.0. production and at low levels due to the improper supply of oxygen, which adversely hamper the growth of the organism. ${ }^{49}$

\section{Media optimization with IPTG and lactose as the inducers}

In this study, the T7-regulated pET 21a (+) vector was used. To determine the transcription efficiency of the $\mathrm{T} 7$ promoter, two inducers, namely IPTG and lactose, were used. This is an important study by IPTG with its low cost analog, lactose, which was used as an inducing agent and produced encouraging results. ${ }^{50}$ Being a natural inducer of lac operon, lactose has proved to be non-toxic to microorganisms and also utilized by microorganisms as a carbon source. ${ }^{17,51}$ Five different media were tested to determine the maximum induction of $\mathrm{T} 7$ promoter for $\alpha$-amylase production, with setting $3 \%$ inoculum, $200 \mathrm{rpm}$ agitation speed, $2 \mathrm{vvm}$ aeration rate, $20 \%$ dissolved oxygen level, and $70 \%$ volume of the medium. The maximum production of $\alpha$-amylase $\left(22.08 \pm 0.11 \mathrm{U} \mathrm{ml}^{-1} \mathrm{~min}^{-1}\right)$ was obtained with $12.27 \pm 0.19 \mathrm{mg} \mathrm{ml}^{-1}$ total protein content when the $\mathrm{T} 7$ promoter of pET 21a (+) was induced with lactose and recombinant $E$. coli was grown in ZBM medium. Similarly, a better yield of $\alpha$-amylase $\left(13.28 \pm 8.26 \mathrm{U} \mathrm{ml}^{-1} \mathrm{~min}^{-1}\right)$ with $8.26 \pm 0.04 \mathrm{mg} \mathrm{ml}^{-1}$ total protein content was obtained when IPTG was used as an inducer in ZBM medium. This ZBM medium is a modified form of $\mathrm{ZB}$ medium ${ }^{52}$ containing tryptone, the amino acid source, more than other tested media. ${ }^{53} \mathrm{~A}$ lower yield of enzyme was produced in M9 medium either induced with IPTG or lactose. Generally, induction with lactose produced better yields in all the media used as compared to induction by IPTG. The total viable cell count in lactose-induced media was $26.49 \times 10^{8} / \mathrm{ml}, 21.73 \times 10^{8} / \mathrm{ml}, 16.46 \times 10^{8} / \mathrm{ml}$, $11.34 \times 10^{8} / \mathrm{ml}$, and $4.74 \times 10^{8} / \mathrm{ml}$ among ZBM, ZYBM9, ZB, LB, and $\mathrm{M} 9$, respectively. While in IPTG-induced media, the total viable cell count was $12.93 \times 10^{8} / \mathrm{ml}, 10.78 \times 10^{8} / \mathrm{ml}, 9.68 \times$ $10^{8} / \mathrm{ml}, 6.09 \times 10^{8} / \mathrm{ml}$, and $1.08 \times 10^{8} / \mathrm{ml}$ among ZBM, ZYBM9, ZB, LB, and M9, respectively (Fig. 8A and B).

\section{Optimization of the desizing potential of $\alpha$-amylase}

In the textile industry, the use of thermostable amylase is very auspicious for the desizing of cotton cloth. The sized fabric is actually hydrophobic in nature and the wet processing, which includes desizing and scouring, is an attempt to make the fabric hydrophilic in nature. Although, the sized fabric would not become completely hydrophilic after the desizing process, after processing, like scouring, the fabric can become completely hydrophilic in nature. In the present study, the desizing potential of this recombinant thermostable amylase was optimized for maximum desizing activity. The effects of temperature, $\mathrm{pH}$, different concentrations of enzyme and time of incubation were checked for the desizing of cotton cloth. A plain weaved $100 \%$ cotton grey fabric was used in this experiment. The alignment of the warps and wefts in the plain weaved fabric was present in a simple crisscross pattern, ${ }^{31}$ which is used more than any other weave. Plain weaved fabric is stronger than any other weave type due to the presence of a greater number of intersections per unit space, all other factors being equal. ${ }^{54} \mathrm{~A}$ fabric piece $(5 \times 5$ inches $)$ was pre-weighed. The pre-weight of 


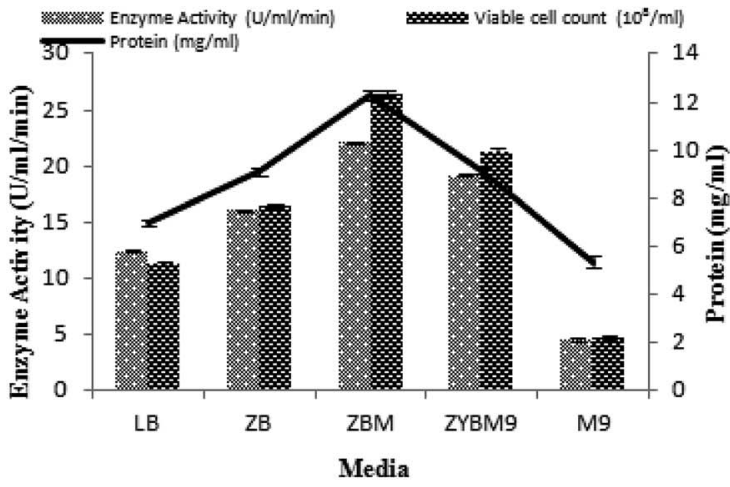

$\mathbf{A}$

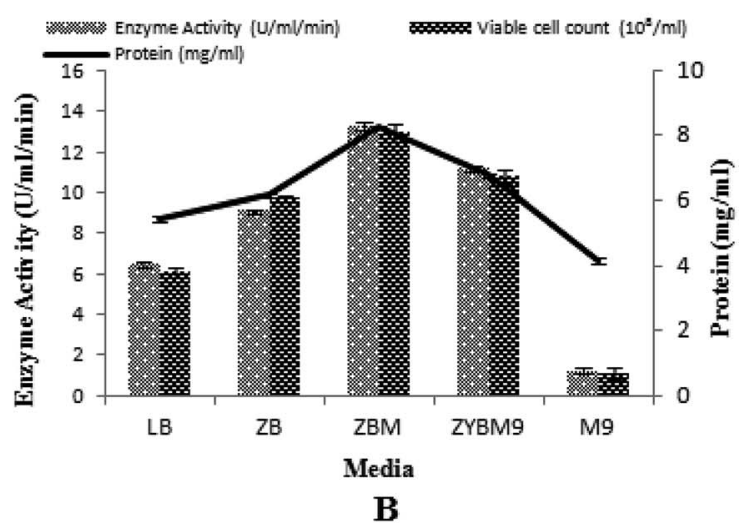

B

Fig. 8 (A) Effect of different media induced with lactose on the enzyme activity. (B) Effect of different media induced with IPTG on the enzyme activity.

the cloth having starch on it was calculated as $13.78 \mathrm{~g}$. The total fiber count was 120 epi in the grey fabric used in this study. The cotton cloth of size $(5 \times 5$ inches) was dipped in $100 \mathrm{ml}$ of $\alpha$ amylase and incubated at various temperatures ranging from $50{ }^{\circ} \mathrm{C}$ to $100{ }^{\circ} \mathrm{C}$ for $60 \mathrm{~min}$. The maximum desizing percentage for cotton cloth was obtained $(74.8 \%)$ at $80{ }^{\circ} \mathrm{C}$ when incubated for $1 \mathrm{~h}$ (Fig. 9A). However, $68.43 \%$ and $62.57 \%$ desizing was obtained at $90{ }^{\circ} \mathrm{C}$ and $100{ }^{\circ} \mathrm{C}$. The effect of $\mathrm{pH}$ was determined on the desizing of the cotton cloth $(5 \times 5$ inches $)$ by incubating it in enzyme of different $\mathrm{pH}$ of buffer ( $\mathrm{pH} 4-9)$. At $\mathrm{pH}$ 7.0, the enzyme maximum desizing of cotton cloth $(75.03 \%)$ was obtained, while decreased desizings of cotton cloth $(45.80 \%$, $62.84 \%, 49.12 \%$, and $36.22 \%$ ) were achieved when the $\mathrm{pH}$ of the enzyme was adjusted to $5,6,8$, and 9, respectively (Fig. 9B). The

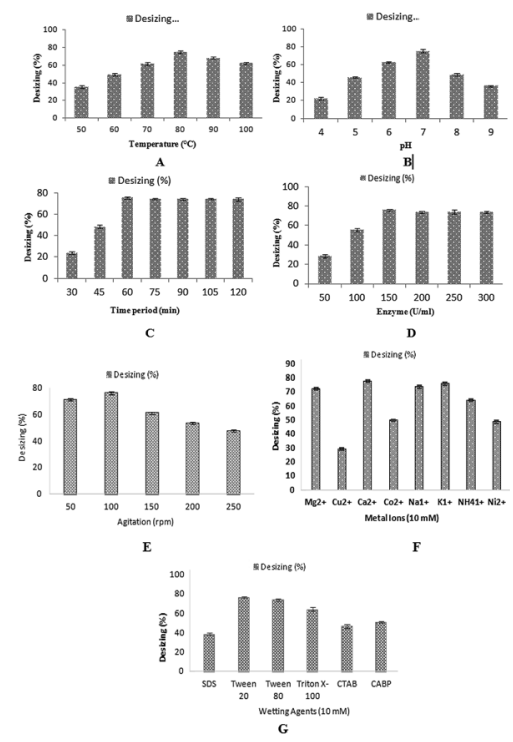

Fig. 9 (A) Effect of incubating temperature on the desizing of cotton cloth. (B) Effect of $\mathrm{pH}$ on the desizing of cotton cloth. (C) Effect of time of incubation on the desizing of cotton cloth. (D) Effect of enzyme concentration on the desizing of cotton cloth. (E) Effect of agitation speed on the desizing of cotton cloth. (F) Effect of metal ions on the desizing of cotton cloth. (G) Effect of wetting agents on the desizing of cotton cloth. effect of the time of incubation was calculated by treating the cotton cloth $(5 \times 5$ inches $)$ with enzyme for $30-120 \mathrm{~min}$ at $80^{\circ} \mathrm{C}$. The maximum desizing $(75.349 \%)$ of the cotton cloth was achieved after incubating it for $60 \mathrm{~min}$ (Fig. 9C). Further increasing the time duration did not affect the rate of desizing, with values of $74.24 \%, 74.09 \%, 74.33 \%$, and $74.16 \%$ desizing obtained after $75,90,105$, and 120 min of incubation respectively. To determine the effect of enzyme concentration on the desizing of the cotton cloth $(5 \times 5$ inches $)$, different enzyme concentrations (50-300 $\left.\mathrm{U} \mathrm{ml}^{-1}\right)$ were used. The cloth was incubated with different concentrations of enzyme with $\mathrm{pH} 7.0$ at $80{ }^{\circ} \mathrm{C}$ for $60 \mathrm{~min}$. With the enzyme concentration of $150 \mathrm{U} \mathrm{ml}^{-1}$, the maximum desizing percentage (75.88\%) was obtained (Fig. 9D). Increasing the concentration of enzyme from this optimal level seemed to inhibit the desizing activity, which might be due to the inappropriate ratio of enzyme to the substrate. ${ }^{54}$ The effect of the agitation rate on the desizing of the cotton cloth by recombinant enzyme was investigated by incubating the cloth with $150 \mathrm{U} \mathrm{ml}^{-1}$ of enzyme at $80{ }^{\circ} \mathrm{C}$ and $\mathrm{pH} 7.0$ for $60 \mathrm{~min}$ at various agitation speeds (50-250 rpm). The maximum desizing $(76.35 \%)$ was achieved at $100 \mathrm{rpm}$ agitation speed, as shown in Fig. 9E. A higher agitation rates resulted in decreased desizing percentages, which might be due to the improper interaction of enzyme with its substrate. Almost $61.16 \%, 53.46 \%$, and $47.74 \%$ desizing was observed at $150 \mathrm{rpm}, 200 \mathrm{rpm}$, and $250 \mathrm{rpm}$, respectively. Similarly, $71.2 \%$ desizing was observed at $50 \mathrm{rpm}$ as shown in Fig. 9E. Various metal ions, including $\mathrm{Mg}^{2+}, \mathrm{Cu}^{2+}$, $\mathrm{Ca}^{2+}, \mathrm{Co}^{2+}, \mathrm{Na}^{1+}, \mathrm{K}^{1+}, \mathrm{NH}_{4}{ }^{1+}$, and $\mathrm{Ni}^{2+}$ were analyzed to determine their effect on the desizing activity of recombinant $\alpha$ amylase enzymes. Most of the metal ions did not show any considerable effect on the activity of enzyme, while in the presence of $10 \mathrm{mM} \mathrm{Ca}^{2+}$ the increased desizing activity (77.7\%) was observed, as shown in Fig. 9F. In the presence of $\mathrm{Mg}^{2+}$, $\mathrm{Cu}^{2+}, \mathrm{Co}^{2+}, \mathrm{Na}^{1+}, \mathrm{K}^{1+}, \mathrm{NH}_{4}{ }^{1+}$, and $\mathrm{Ni}^{2+}$, the desizing activity was $72 \%, 29 \%, 49 \%, 73 \%, 75 \%, 64 \%$, and $48 \%$, respectively, as shown in Fig. 9F. Different ionic, nonionic, and amphoteric wetting agents, including SDS, Tween 20 , Tween 80 , Triton X100 , CTAB, and CABP, were used in $10 \mathrm{mM}$ concentration to determine their effect on the desizing potential of recombinant $\alpha$-amylase enzyme. The results obtained showed that $\alpha$-amylase 


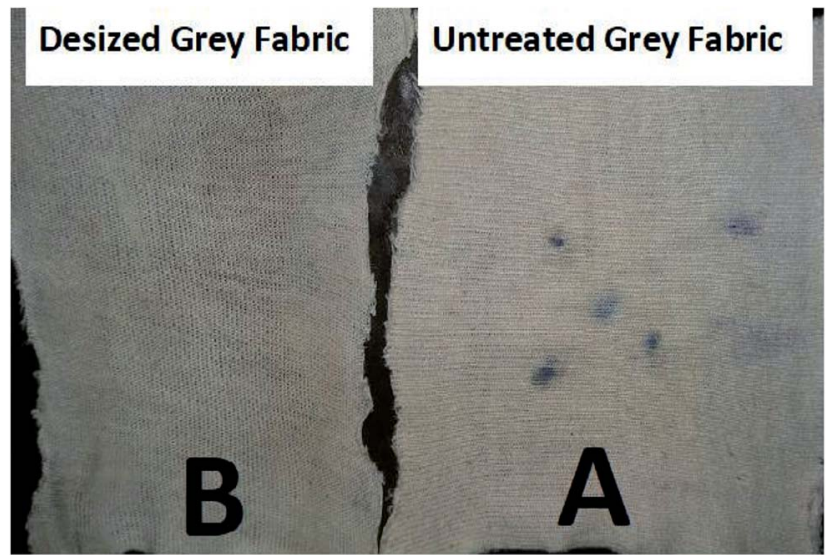

Fig. 10 Assessment of the desizing potential of recombinant $\alpha$ amylase enzyme on grey fabric: (A) the spots present on untreated grey fabric are purple, (B) no spot on the desized fabric.

retained $76 \%, 73 \%$, and $64 \%$ desizing activity in the presence of Tween 20, Tween 80, and Triton X-100, respectively, as shown in Fig. 9G. However, ionic and amphoteric wetting agents, including SDS, CTAB, and CABP, reduced the desizing activity of $\alpha$-amylase to $38 \%, 47 \%$, and $51 \%$, respectively. This reduction in activity might have resulted due to the distortion in the enzyme-substrate complex as well as due to change in electrostatic potential of the substrate due to the adsorption of ionic wetting agents. ${ }^{55,56}$

\section{Assessment of the desizing effectiveness by $\alpha$-amylase enzyme}

To assess the effectiveness of the desizing efficiency of grey fabric by recombinant $\alpha$-amylase enzyme, the iodine solution test was used before and after desizing of the grey fabric. The results obtained after the iodine test are represented in Fig. 10. A very clear purplish spot appeared following the application of iodine solution on untreated grey fabric, while after desizing by the enzyme no such purple color appeared on the grey fabric. These results confirmed that starch present as a sizing agent in the grey fabric was completely hydrolyzed by the application of the recombinant $\alpha$-amylase enzyme.

\section{Research involving human participants and/or animals}

Authors claimed that the present research work does not include any human or animal study.

\section{Informed consent}

Authors included in the study showed willingness to submit research work in the journal and informed consent was obtained from all individuals.

\section{Funding}

Funding for this project was provided by Higher Education Commission, Pakistan as PhD research work for Dr Asma Zafar.

\section{Conflicts of interest}

The authors declare that they have no conflict of interest.

\section{References}

1 P. M. d. Souza, Braz. J. Microbiol., 2010, 41, 850-861.

2 G. Rajagopalan and C. Krishnan, Bioresour. Technol., 2008, 99, 3044-3050.

3 N. Reddy, A. Nimmagadda and K. S. Rao, Afr. J. Biotechnol., 2004, 2, 645-648.

4 A. Pandey, P. Nigam, C. R. Soccol, V. T. Soccol, D. Singh and R. Mohan, Biotechnol. Appl. Biochem., 2000, 31, 135-152.

5 M. S. Tanyildizi, D. Özer and M. Elibol, Process Biochem., 2005, 40, 2291-2296.

6 S. Ghorai, S. P. Banik, D. Verma, S. Chowdhury, S. Mukherjee and S. Khowala, Food Res. Int., 2009, 42, 577-587.

7 R. Gupta, P. Gigras, H. Mohapatra, V. K. Goswami and B. Chauhan, Process Biochem., 2003, 38, 1599-1616.

8 I. Bentley and E. Williams, Industrial enzymology, Stockton Press, New York, NY, 2nd edn, 1996, pp. 339-357.

9 B. Karakaş, M. İnan and M. Certel, J. Mol. Catal. B: Enzym., 2010, 64, 129-134.

10 N. Sidkey, M. Abo-Shadi, R. Balahmar, R. Sabry and G. Badrany, International Research Journal of Microbiology, 2011, 2, 96-103.

11 E. Leveque, S. Janecek, B. Haye and A. Belarbi, Enzyme Microb. Technol., 2000, 26, 3-14.

12 N. Oganesyan, I. Ankoudinova, S.-H. Kim and R. Kim, Protein Expression Purif., 2007, 52, 280-285.

13 A. Gombert and B. Kilikian, J. Biotechnol., 1998, 60, 47-54.

14 A. Suurnakki, M. Niku-Paavola, J. Buchert and L. Viikari, Enzymes Indust, Wiley-VCH, Weinheim, 2004, pp. 232-244.

15 F. W. Studier, A. H. Rosenberg, J. J. Dunn and J. W. Dubendorff, Methods Enzymol., 1990, 185, 60-89.

16 B. Kilikian, I. Suárez, C. Liria and A. K. Gombert, Process Biochem., 2000, 35, 1019-1025.

17 H. B. Zhang, X. Q. Mao, Y. J. Wang and X. Q. Hu, J. Food, Agric. Environ., 2009, 7, 75-78.

18 P. Howhan and S. Pornbanlualap, ScienceAsia, 2003, 29, 347353.

19 S. Sankaralingam, T. Shankar, R. Ramasubburayan, S. Prakash and C. Kumar, Am.-Eurasian J. Agric. Environ. Sci., 2012, 12, 1507-1513.

20 R. Prakasham, C. Subba Rao, R. Sreenivas Rao and P. Sarma, J. Appl. Microbiol., 2007, 102, 204-211.

21 T. Zangirolami, M. Carlsen, J. Nielsen and S. B. Jorgensen, Braz. J. Chem. Eng., 2002, 19, 55-68.

22 R. Abdullah, I. U. Haq and M. Javid, Pak. J. Bot., 2011, 43, 715-723.

23 P. Gigras, V. Sahai and R. Gupta, Curr. Microbiol., 2002, 45, 203-208. 
24 S. Ahlawat, S. S. Dhiman, B. Battan, R. Mandhan and J. Sharma, Process Biochem., 2009, 44, 521-526.

25 D. Saravanan, A. Arul Prakash, D. Jagadeeshwaran, G. Nalankilli, T. Ramachandran and C. Prabakaran, Indian J. Fibre Text. Res., 2011, 36, 253.

26 S. Sivaramakrishnan, D. Gangadharan, K. M. Nampoothiri, C. R. Soccol and A. Pandey, Food Technol. Biotechnol., 2006, 44, 173-184.

27 S. N. Cohen, A. C. Chang and L. Hsu, Proc. Natl. Acad. Sci. U. S. A., 1972, 69, 2110-2114.

28 M. M. Bradford, Anal. Biochem., 1976, 72, 248-254.

29 U. K. Laemmli, Nature, 1970, 227, 680-685.

30 G. L. Miller, Anal. Chem., 1959, 31, 426-428.

31 R. D. Karnik and L. S. Admuthe, International Journal of Engineering Research and Technology, 2017, 10, 452-456.

32 Z. A. L. Malik, A. Tanwari and H. U. R. Sheikh, Mehran Univ. Res. J. Eng. Technol., 2017, 30, 23-28.

33 S. N. Sreelakshmi, A. Paul, N. S. Vasanthi and D. Saeavana, J. Text. Inst., 2013, 59-56.

34 N. Manivasakam, Water used in textile processing quality, treatment and analysis, Sakthi Publication, Coimbatore, 1995, vol. 155, p. 160.

35 I. Haq, S. Ali, M. Javed, U. Hameed, A. Saleem, F. Adnan and M. Qadeer, Pak. J. Bot., 2010, 42, 473-484.

36 M. K. Chimata, C. S. Chetty and C. Suresh, Biotechnol. Res. Int. , 2011, 1-8.

37 S. Harane and R. V. Adivarekar, Textiles and Clothing Sustainability, 2016, 2, 2, DOI: 10.1186/s40689-016-0012-7.

38 M. D. Teli and T. T. Adere, International Journal of Engineering Trends and Technology, 2016, 35(6), 1-8.

39 C. Vieille and J. G. Zeikus, Trends Biotechnol., 1996, 14, 183190.
40 L. L. Lin and W. H. Hsu, Lett. Appl. Microbiol., 1997, 24, 365368.

41 A. Sabu, A. Pandey, M. J. Daud and G. Szakacs, Bioresour. Technol., 2005, 96, 1223-1228.

42 H. Patel, A. Gupte and S. Gupte, Bioresearch, 2009, 4, 268284.

43 B. K. Hwang, W. N. Lee, K. M. Yeon, P. K. Park, C. H. Lee, i. S. Chang, A. Drews and M. Kraume, Environ. Sci. Technol., 2008, 42, 3963-3968.

44 S. Korshunov and J. A. Imlay, J. Bacteriol., 2006, 188, 63266334.

45 J. A. Imlay, Annu. Rev. Biochem., 2008, 77, 755.

46 K. R. Messner and J. A. Imlay, J. Biol. Chem., 1999, 274, 10119-10128.

47 H. Mukhtar and H. ul Ikram, Pak. J. Bot., 2007, 39, 27052715.

48 H. ul Ikram, H. Mukhtar and N. Umber, Pak. J. Zool., 2008, 40, 69-73.

49 V. Nigam, A. Khandelwal, A. Agarwal, M. Mohan and A. Vidyarthi, Int. J. Biosci. Biotechnol., 2012, 4, 81-89.

50 H. Galehdari and M. Roayaei, Jundishapur J. Microbiol., 2008, 1, 1-5.

51 J. Yan, S. F. Zhao, Y. F. Mao and Y. H. Luo, World J. Gastroenterol., 2004, 10, 1755-1758.

52 U. Hameed and M. A. Khan, Int. J. Agric. Biol., 2014, 16, 836840.

53 F. W. Studier, Protein Expression Purif., 2005, 41, 207-234.

54 B. Allan, B. Torbenvedel and B. F. Henrick, PTC Int. Appl., 1997, 12, 205-210.

55 N. A. Ibrahim, M. El-Hossamy, M. S. Morsy and B. M. Eid, Polym.-Plast. Technol. Eng., 2004, 43, 519-538.

56 S. D. Fried and S. G. Boxer, Annu. Rev. Biochem., 2017, 86, 387-415. 